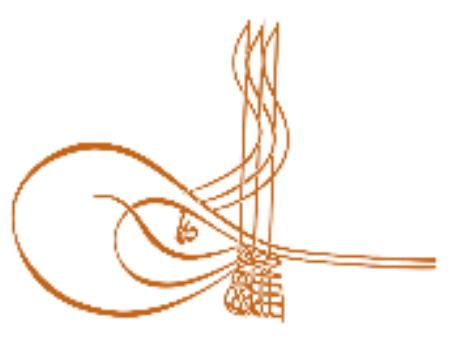

www.turkishstudies.net/turkishstudies
Turkish Studies

eISSN: $1308-2140$

Research Article / Araștırma Makalesi

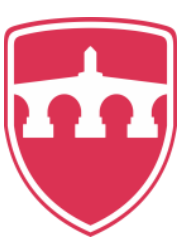

INTERNATIONAL

BALKAN

UNIVERSITY

Sponsored by IBU

\title{
John Dewey’in Demokrasi ve Eğitim Anlayışının Atatürk Dönemi Eğitim Politikasına Yansimalari*
}

\author{
Reflections of John Dewey's Understanding of Democracy and Education on the Principle of \\ Education in the Ataturk Period
}

\author{
Nursel Gülcü*
}

\begin{abstract}
One of the most important elements of being a modern state is to create a society consisting of cultured and educated individuals. In this way, society can keep up with the changes in the world. On the other hand, the education system not only transfers the accumulated culture to the new generations, but also evaluates the mistakes to find the right new elements. With Atatürk, the primary objective of the young republic was to create such a society. At the invitation of Atatürk in 1924, John Dewey also came to Turkey in the report which was prepared "Education is a prerequisite for the functioning of democracy, saying," student raising has also stressed the importance of giving democratic education. According to Dewey, democratic society based on the individual's own creative policy and voluntary participation in social life and working for the good of society. This study aims to examine John Dewey's understanding of education and democracy and its objectives in education, its reflections and similarities in education studies and education policy of Atatürk. According to John Dewey, since the new generation is unaware of the goals and habits of the social group they are in, education is the only force that can actively engage in awareness of goals and habits and can lift the gap. When Atatürk's education policy and objectives in the Republican Period are evaluated, it is seen that the priority is the education of the people, and it attaches importance to education and cultural development primarily on the basis of economic development. First of all, Atatürk, who wanted to claim the Republic, democracy and the revolutions made within this framework, saw the main element of being a modern state as the education of the people. At this point, we can say that John Dewey's understanding of education and democracy has been expressed in programmatic studies in Atatürk's education policy.
\end{abstract}

Structured Abstract: John Dewey, who came to Turkey in 1924 at the invitation of Atatürk, came to Turkey on July 24, and conducted investigations in Istanbul Darülfünun, high schools, teachers' schools and professional associations until August 15. Within the concept of democratic education, the idea of democracy and democratic education was described as the process of structuring scientific society. Much of Dewey's

\footnotetext{
" BU makale Üsküp'te düzenlenen Uluslararası Sosyal Bilimler Kongresi - INCSOS’ta bildiri olarak sunulmuştur.

${ }^{*}$ Dr. Öğr. Üyesi, Akdeniz Üniversitesi, Eğitim Fakültesi, Temel Eğitim Bölümü

Asst. Prof. Dr., Akdeniz University, Faculty of Education, Department of Basic Education

ORCID 0000-0002-4488-0252

nur.gulcu@gmail.com

Cite as/ Atıf: Gülcü, N. (2020). John Dewey'in demokrasi ve eğitim anlayışının Atatürk dönemi eğitim politikasına yansımalar1, Turkish Studies, 15(1), 251-262. https://dx.doi.org/10.29228/TurkishStudies.37356

Received/Geliş: 19 September/Eylül 2019

Accepted/Kabul: 25 February/Şubat 2020

Copyright $\mathbb{C}$ MDE, Turkey
} 
philosophy is about education. According to Dewey, the whole philosophy of education can be counted. Dewey believed that he would achieve the philosophy he intended to rebuild with education. Dewey has seen democracy and education synonymous all his life.

According to J. Dewey, it's the first time he's been in a position to do anything about it. Democracy contains much more than a form of governance. It is essentially an organized lifestyle, a free combination of common experiences. While underlining the fact that dividing into separate classes will have deadly effects, he states that in societies where there are sharp class distinctions, only the ruling class will be interested in education, and for a volatile society the situation should be different.

According to him, all segments of the nation should be offered equal equipment for future careers. In order to achieve these objectives, we have to do the same school services should be managed and family resources should be used to enable young people to benefit from school services.

At the end of his work, in the introduction to the original report written by J. Dewey in Turkey; "the first and very important point is to determine the objectives and objectives of The Schools of Turkey," he said, adding that with a clearly targeted programme, educational institutions could also be made of unnecessary changes and ineffective measures to be taken in the name of so-called rehabilitation. he wrote that it would be protected.

In Dewey's report, some of his recommendations stand out. Especially in order for teachers' schools to have a variety of courses to train students in certain areas, at least to open an "Experience School" in a teacher's school, and to allow teachers to improve themselves, establishing, reading books on education, discussing these books, translating and saving education from uniformity in an environment where they will share their own experiences by being aware of developments in foreign countries, it is possible to convert them into institutions that enable scientific studies.

That each part of the school system has integrity in itself, that schools are organizing their programs from primary school to prepare for university, and as a result of "students who finish primary and secondary school and do not go to university, that they lack the means to express themselves and turn to a profession, and that a student must have achieved a specific purpose whether he or she goes to university or not."

According to him, curriculum programs should be arranged in various parts of the country to accommodate local needs. There must be a connection between school classes and life. In this way, he wants to address the circumstances of the country at that time. It recommends that schools after primary school be divided into various fields of agriculture, industry and commercial, as well as schools providing science and foreign language education in certain cities. As a foreign language, several foreign languages other than French should be determined according to the objectives and regional needs of the school.

Some of the recommendations in j. Dewey's report, prepared in 1924 and presented to Turkish national education, appear to have been reflected in the 1926 program. With the 1926 program, the relationships between the courses were given importance, and the old program showed the courses "Nature Survey", "Country Knowledge", "History and Geography" and "Health Information" separately, while in the new program, these courses were combined under the name of "Life Knowledge" and it has been accepted as the main course that forms the basis of education.

The 1926 program is of importance among other programs. It contains the basic principles on which today's programs are based. The 1926 program is also important because it covers the six basic principles on which today's programs are based.

1. Collective education system

2. Primary school objectives

3. Special purposes of courses

4. Paths to follow in teaching

5. Method of analysis applied in the first literacy teaching

6. Separation of 5-class elementary school into the first and second phase 
J. Dewey's words that "the teacher is the way the school is, so can the schools" depends on improving schools and improving the quality of life, improving the living conditions of teachers and improving their qualifications.

Mustafa Necati is a Minister of Education who is at the forefront of Atatürk's staff for the revolutions. There is a serious similarity between M. Necati and J. Dewey's understanding of school and education. Mustafa Necati was both influenced by J. Dewey's conception of "Democracy and Education", and was a minister of education who had all of his proposals in J. Dewey's report and tried to carry out it under the conditions of the Republic. After Necati's death, education-related studies continued uninterrupted until Atatürk's death.

Atatürk believed that the only magic key to nationhood and nationlike development was in the power of the people, and with this idea, he first established Community Centres after some experiments to educate, educate and adapt to the era.

With the opening of Community Centres during Atatürk's period and the fact that all the people are in the city and the Community Centre's activities with the peasants, it shows that democracy is an area where the principles of equality, justice, public participation and citizenship are best implemented.

It is possible to see almost the vast majority of the examples of philosophy, studies and practices to be carried out in the states established on the basis of national sovereignty in the name of "Democracy and Education" by J. Dewey for the opening purposes and activities of Community Centres.

Consequently, J. Dewey emphasizes the important power of education in achieving democracy while at the same time demonstrates the importance of using it. In order to do this, the people need to be educated altogether.

According to J. Dewey, in order to raise citizens who are capable of maintaining the Republic and democracy, the people must first be educated and educated by the principle of equality based on the needs of the people.

Looking at the work done until Atatürk's death; it is seen that cultural development is aimed at bringing the people into administration, increasing the level of knowledge and consciousness of the people and opening institutions in this direction. In order to achieve these objectives, we can say that education has been seen as a tool and the objectives have been achieved.

Keywords: Atatürk, democracy, education, John Dewey.

Öz: Çağdaş devlet olmanın en önemli öğelerinden biri kültürlü ve eğitimli bireylerden oluşan bir toplum oluşturmaktır. Bu şekilde toplum dünyadaki değişime ayak uydurabilir. Diğer taraftan eğitim sistemi, yalnızca birikmiş kültürü yeni kuşaklara aktarmakla kalmaz aynı zamanda hataları değerlendirerek doğru olan yeni ögeler bulunmasını sağlar. Atatürk'le birlikte genç Cumhuriyet'in öncelikli hedefi de böyle bir toplum ortaya çıkarmak olmuştur. Atatürk'ün 1924 yılında davetiyle Türkiye'ye gelen John Dewey de hazırlamış olduğu raporda "Eğitim, demokrasinin işlemesi için ön koşuldur" diyerek, öğrenci yetiştirme de demokratik eğitim verilmesinin önemini vurgulamıştır. Dewey'e göre, demokratik toplumun temelini, bireyin kendi yaratıcı politikasını toplumsal yaşama gönüllü olarak katılmasıyla ve toplumun iyiliği için çalışarak ortaya çıkarması olarak görmektedir. Bu çalışma, John Dewey’in eğitim ve demokrasi anlayışını ve eğitim ile ilgili hedeflerini, Atatürk Dönemi eğitim çalışmalarında halkevlerinin kuruluş sürecine dek olan sürede yapılan faaliyetler çerçevesinde; yansımalarını ve benzerliklerini ele almayı amaçlamaktadır. John Dewey’e göre yeni nesil, dünyaya geldikleri sosyal grubun amaçlarından ve alışkanlıklarından habersiz olduklarından, eğitim, amaçların ve alışkanlıkların farkına varmada aktif olarak ilgi göstermede ve aradaki uçurumu kaldırabilecek tek güçtür. Atatürk'ün de Cumhuriyet Dönemi eğitim politikası ve hedefleri değerlendirildiğinde önceliğinin halkın eğitimi olduğu, ekonomik kalkınmanın temelinde öncelikle eğitim ve kültürel kalkınmaya önem verdiği görülmektedir. Öncelikle cumhuriyet, demokrasi ve bu çerçevede yapılan inkılapları halka mal etmek isteyen Atatürk, çağdaş bir devlet olabilmenin ana unsurunu, öncelikle halkın eğitilmesi olarak görmüştür. Bu noktada John Dewey'in eğitim ve demokrasi anlayışı Atatürk Dönemi eğitim politikasında programlı çalışmalarla ifade edilmiştir diyebiliriz. Çalışmanın Yöntemi, J. Dewey’in” Demokrasi ve Eğitim Kitabı, J. Dewey’in 1924 tarihli roporu incelenecek, Atatürk Dönemi eğitim politikalarındaki demokrasi ve eğitim anlayışıyla karşılaştırması 
yapılacaktır. Bununla ilgili arşiv belgelerinden, süreli yayınlardan ve kaynak eserlerden yararlanılacak, doküman analizi tekniğinden yararlanılacaktır. Çalışma aynı zamanda derleme çalışması niteliğindedir.

Anahtar Kelimeler: Atatürk, demokrasi, eğitim, John Dewey.

\section{Giriş}

J. Dewey, kökenleri aydınlanma dönemi değerlerine kadar uzanan özgürlükçü eğitim geleneğinin önemli bir temsilcisidir (Özsoy, 2006:1897-1898). J. Dewey, yaklaşık bir asırlık ömrü boyunca işe, eyleme dönük pratik bir felsefe olarak nitelendirilen pragmatizmi bir dünya görüşüne dönüştürmüş felsefe problemlerinin yanı sıra sosyal problemlere, birey ve toplum hayatının geneline uygulanabilir bir biçime sokmaya çalışmıştır (Yılmaz,2009:80).

1896 y1lında Chicago Üniversitesinde kurduğu "Laboratuvar Okulu" ile eğitim bünyesinde 4-14 yaş grubu çocuklarının aktif öğretim yöntemleri konusunda eğitim vererek, yöntemin ve yönetimin, eğitim alanında uygulanışının ilk örneğini vermiş̧ir (Yeşiltaş ve Kaymakçı, 2009:227228).

J.Dewey, demokratik eğitim kavramı içerisinde demokrasi ve demokratik eğitim düşüncesini, bilimsel toplumun yapılandırılma süreci olarak nitelendirilmiştir. Dewey'in felsefesinin büyük bir kısmı eğitimle ilgilidir. Dewey'e göre bütün felsefe eğitim felsefesi sayılabilir. Dewey, yeniden inşa etmeyi düşündüğü felsefeyi eğitimle gerçekleştireceğine inanıyordu. J. Dewey, bütün hayatı boyunca demokrasi ile eğitimi eş anlamlı görmüştür.

"Demokrasi ve eğitim" başlığı altında Dewey'in ortaya koymak istediği düşünce aslında “demokrasi” anlayışı ile yapılandırılmış bir eğitim anlayışıdır (Doğa, 2004:173). Dewey'in Demokrasi düşüncesi yine O'nun felsefesinin hemen hemen tamamını oluşturan eğitim düşüncesi ile bütünleşmektedir.

\section{John Dewey'in Demokrasi ve Eğitim ile İlgili Görüşleri}

J.Dewey bir toplumda amaçlı ve sistematik bir eğitimin nasıl çıkacağı ile ilgili bazı görüşler ortaya koymuştur. Öncelikle çıkarların iç içe geçerek karşılıklı olarak birbirini etkilediği bir toplumsal yaşam türünde ve gelişime ya da yeniden yapılanmaya açık toplumda, amaçlı ve sistematik bir eğitimin ortaya çıkacağını ileri sürerken, demokratik bir topluluğun da bu açıdan diğer bir toplulukların ötesine geçeceğini söylemiştir. Yine "halkın oyları ile iş başına gelen bir hükümetin ve onu iş başına getiren insanların da kurallara uyan ve eğitimli olmadıkça da başarılı olabilmesi mümkün değildir" diyerek demokratik bir idarenin eğitimli bir toplumla başarılı olabileceğini, aynı zamanda "Demokratik bir toplum dış otorite ilkesini yadsıyacağından, gönüllü bir uzlaşma ve ortak çıkar ilkelerini esas alır" diyerek de demokratik toplum kavramına daha derin bir açıklama getirmiş̧ir.

J. Dewey demokrasiye çok geniş bir açıdan bakar ve J. Dewey' e göre demokrasi bir yönetim biçiminden çok daha fazla şeyler içerir. Ona göre esasında demokrasi, örgütlenmiş bir yaşam türünün, ortak deneyimlerinin özgür bir tarzda bir araya getirilmesidir. J. Dewey, ayrı sınıflara bölünmenin ölümcül etkileri doğuracağı gerçeğinin altının çizerken, keskin sınıf ayrımlarının bulunduğu toplumlarda sadece hâkim sınıfin eğitime ilgi göstereceğini, değişken bir toplum içinse durumun farklı olması gerektiğini belirtir (Dewey, 2004:105-106).Bu noktadan bakıldığında da demokrasinin birleştici özelliği üzerinde durmaktadır.

J.Dewey için öncelikle neden var olduğumuzu ve bu çerçevede varoluşun amacını ortaya koymak önemlidir, Platoncu eğitim felsefesi üzerinden de varoluşun amacını ortaya koymaya çalışır. "Varoluşun amacını bilemezsek, rastgelen ve kaprisli hareket ederiz" diyerek, sosyal düzenlemelerin 
nasıl olması gerektiğini akılcı bir biçimde tespit kriterlerine ihtiyacı olduğunu ortaya koymaktadır. (Dewey, 2004:107).

J. Dewey, Platon'nun eğitim felsefesinin toplumsal düzenlemelerin nasıl olması gerektiği üzerinde ki akılcı kriterlerini önemserken, eğitimin toplumsal değişimler ve etkileşimler üzerindeki etkisini yadsıyan Platon felsefesine de bir nevi eleştirel bir bakış açısı ve açılama getirerek; Platon'un felsefesinin kırılma noktasını, eğitimdeki gelişmelerin daha iyi bir toplum yaratacağına güvenmemesine ve eğitimin daha iyi bir toplum yaratacağı, bunun sonucunda da o toplumun da eğitimi geliştireceği ve bu karşl1ıklı etkileşimin sonsuza dek süreceğini kabullenmemiş olduğunda görür. (Dewey, 2004:109).

Dewey, her şeyi eğitime bırakmak fikrini de eleştirir. Her şeyi eğitime bırakmanın eğitim fikrini inkâr etmekten başka anlama gelmeyeceğini söylerken, "eğitim şansa kalmış olacaktır" der. Eğitim sürecinin gerçekleştirilmesi için sadece yöntemleri değil, aynı zamanda pozitif organları ve yönetsel kurumları da gerektirdiğini ve yeni bir toplum yaratmaya adanan yeni eğitimin geçekleştirilmesi, her şeyden önce var olan devletlerin etkinliklerine bağl1 olduğunu öne sürer. J.Dewey, Avrupa'dan örnekler vererek, devlet destekli eğitim fikrini, tarihsel koşullar gereği siyasi yaşamdaki ulusçu hareketlerle özdeşleştirmiştir. Almanya ile ilgili örneğinde; Alman düşünce yapısının etkisiyle, eğitimin bir yurttaşlık görevine dönüştügünü, yurttaşlık görevi ile ulus devlet idealinin gerçekleştirilmesiyle birlikte geçmişteki insanlık ideali olan "devlet" ile "kozmopolitanlık" idealinin yerini de ulusçuluğun aldığını ve Almanlar'ın eğitime gösterdiği sistematik ilgiyle, siyasi birliği ve güce ulaşmanın ya da onu korumanın en önemli aracı olduğunu hissettiklerini ve tarihi olayların da bunu doğruladığını belirtir. Bölünmüş̧ Almanya'nın Prusyalı devlet adamlarının önderliğinde, kapsamlı ve özenli bir eğitim sistemi geliştirmeye ihtiyaç duyduklarını da bu örneklerine ekler (Dewey, 2004:111-112).

J. Dewey'in demokrasi anlayışında; devlet, kamusal eğitimin yalnızca araçlarını değil, amacını da belirler. İlkokullardan üniversitelere kadar tüm okul sistemi, vatansever yurttaşlar ve askerler, geleceğin devlet memurlarını ve yöneticilerini yetiştirmek üzere kurulmuştur. Okullar, askeri, endüstriyel ya da siyasi savunma ve yayılmacılığın araçlarını sağlar. Pratikte durumu bu şekilde açıklarken, teorik olarak eğitimin sosyal verimliliğin amacını vurgulaması da imkânsız hale gelecektir fikrini ortaya koyar.

J. Dewey 'de ulusal egemenlik kavramı, bireylerin, devletin askeri savunmada ve ticarette uluslararası üstünlük için mücadele gibi yüce menfaatlerine tabi olmasını gerektirir. Bir başka açıdan da ulusal egemenlik fikrinin, siyaset dünyasında hiçbir zaman olmadığı kadar belirleyicilik kazandığını, her ulusun, komşularına karşı bastırılmış bir düşmanlığının ve savaş tehditlerinin eksik olmadığı bir dünya tablosu çizer. Her ulusun çıkarlarının koruyucusu olmasını beklerken, her ulusun sadece kendine özgü çıkarlara sahip olduğunu kabul eder. Bu durumu sorgulamayı ise, siyasi pratiğin ve siyasal biliminin temeli olarak kabul edilen ulusal egemenlik fikrini sorgulamakla eş anlamlı görür (Dewey, 2004:115-116).

J. Dewey, günümüzdeki ekonomik koşullar çerçevesinde, toplumu sınıflara ayıran ve bazı sınıfları hâkim kültürün birer aracı haline dönüştüren eğitimle yüzleşmeyi zorunlu görürken okul hizmetlerinin önemine dikkat çeker; "Okul, hizmetlerinde öylesine bolluk ve verimlilik sağlamalıdır ki ekonomik eşitsizliklerin etkileri sadece lafta değil, pratikte de ortadan kaldırılabilmelidir". J.Dewey'e göre, ulusun her kesimine gelecek kariyerleri için eşit donanım sunulmalıdır. Bu amaçlara ulaşmak içinse; okul hizmetlerinin uygun bir biçimde yönetilmesi ve ailevi kaynakların, gençleri okul hizmetlerinden yararlanmasını sağlayacak şekilde kullanılması gerektiğini vurgular. Bunların yanı sıra, geleneksel kültür ideallerinin, geleneksel eğitim temalarının, geleneksel eğitim ve disiplin yöntemlerinin, tüm gençleri kendi ekonomik ve sosyal kariyerleri için gerekli araçlarla donatacak şekilde belirlenmesi gerektiğini, eğitimin demokratik idealinin de, kamusal eğitim sistemini giderek daha çok belirleyen bir ideali olmadıkça, trajikomik bir hayal olmanın ötesine geçemeyeceğini 
belirtir ve savaşların yarattığı felaketleri anlatmak ve uluslar arasında kıskançlık ya da düşmanlığı besleyen her şeyden kaçınmak yeterli değildir ve bunun için coğrafi sınırların ötesinde insanları birleştiren ortak insani değerler ve hedeflere vurgu yapılması gerektiğini belirtir. "Eğitim fikrinin kendisi, bireysel kapasitelerin sosyal hedefler doğrultusunda özgür kılınmasını içerir" derken, aksi takdirde eğitimin demokratik ölçütünün tutarlı bir biçimde uygulanamayacağını savunur.

Sonuç olarak John Dewey, "deneyimlerinden her üyesinin eşit bir biçimde faydalanmasına olanak veren ve farklı örgütlü yaşam türlerinin etkileşimi aracılığıyla, kurumların esnek yapısını koruyan bir toplum demokrasi kriterlerini yerine getirecektir" demekle, toplumsal yapı içerisinde vatandaşların firsat eşitliğine sahip olmasının altını çizer ve kurumlar arasındaki etkileşimin demokrasi için gerekliliğini belirtir. Demokratik bir toplumda, bireylerin sosyal ilişkileri kontrole ilgi duyması ve bu şekilde toplumsal karmaşadan uzaklaşarak sosyal değişimlere açık zihinsel alışkanlıklar kazanacağını ve bunun da eğitim sistemiyle mümkün olduğunu söyler (Dewey, 2004:117-118).

J.Dewey, "Demokrasi ve Eğitim" kitabından yaklaşık 20 yıl sonra yayınladığı "Deneyim ve Eğitim" kitabında da "demokratik ve toplumsal düzenlemelerin, demokratik olmayan veya demokrasi karşıtı olan toplumsal yaşam biçimleriyle kıyaslandığında, çok daha kaliteli ve çok daha fazla kişi tarafından ulaşılıp sevilen bir insan deneyimi sağladığg sonucuna varmayacak tek bir mantık bulabilir miyiz?" sözleriyle de toplumsal hayatın düzenlenmesindeki önemli görevine bir kez daha dikkat çekmiştir (Dewey, 2014:14).

Dewey, "Özgürlük ve Kültür” kitabında ise; "hepimiz insanllk tarihinin demokratik olmayan ve demokrasiye karşı olan uzun geçmişini ve demokrasinin yeni bir şey olduğunu öne sürerek önümüzdeki işin büyüklügünü ileri sürmekte haklı sayılabiliriz" (Dewey, 1964: 177) sözleriyle de demokratik bir yaşam anlayışını, insanlık geçmişindeki birçok karşı çıkmaların ve demokratik olmayan yaşantıların dikkate alınmasıyla beraber, ideal bir demokratik düzene ulaşmanın kolay olmadığını da ayrıca belirtir.

\section{Dewey'in Türkiye'ye Davet Edilmesi ve Türk Maarifi Hakkındaki Raporu}

J. Dewey'in Türkiye'ye davetinde meşhur zenginlerden ve Amerika'da okuyan Türk öğrencilere burs temin eden Mr. Crain'in Türk eğitim sistemiyle ilgili planlar yaptırmak ve bütün masrafları üzerine alacak şekilde bir sene süreyle Kolombiya Üniversitesi profesörlerinden J. Dewey’i getirtme talebini maarif vekâleti ne iletmesi önemli bir etkendir (BCA, 06.08.1923).

Mr. Crain'in teklifinin Maarif Vekâleti tarafindan uygun görülmesi üzerine, Türk ilköğretiminin şekillenmesine yardımcı olmak üzere Türkiye ye gelmesi kabul edilen John Dewey’e bir davet mektubu gönderilecektir (BCA, 26.09.1923). Amerikalı eğitimci Dewey'in bir sene süre ile Türkiye'deki masraflarını karşılayan Amerikalı zenginlerden Crain'e Maarif Vekaleti mektupla teşekkürlerini bildiren 03.02.1924 tarihli bir yazı gönderecektir (BCA, 03.02.1924).

İsmail Sefa'nın (Özler) Maarif Vekaleti döneminde mektup yazılarak Türkiye'ye davet edilen Dewey'e başvurulma nedenlerinde biri de demokrasi sisteminde nasıl bir eğitim uygulanacağ 1 ve demokratik topluma uygun öğretmen kadrosunun nasıl yetiştirileceği konusunda fikirlerini almaktı (Ata, 2001: 194). Dewey ise; Cumhuriyet ve Hakimiyet-i Milliye Gazetelerine verdiği demeçte, kendisinin Türkiye'ye danışman olarak görev almak için gelmediğini, Amerika'da Türkiye'yi sevmekle tanınan Mr. Charles R. Crain'in teşvikiyle bilimsel araştırma amacıyla geldiğini belirtmektedir (Ata, 2013: 878).

24 Temmuz'da Türkiye'ye gelen J. Dewey, İstanbul Darülfünun'da, liselerde, öğretmen okulunda ve meslek derneklerinde 15 Ağustos'a kadar incelemeler yaptı. Ankara'ya hareketinden önce basına Türkiye'de neler yapacağına dair bir mektup yazarak "eğitim sistemini düzenlemek için geldiğini, kendi fikirlerini kabul ettirmek ya da başka bir ülkenin eğitim sistemini kabul ettirmek niyetinde olmadığını" bildirmiştir. 
John Dewey, Ankara'da Atatürk tarafindan kabul edildikten sonra Muallimler Kongresi'ne katıld1. Ankara'da on gün kaldıktan sonra tekrar İstanbul'a dönen Dewey, Türkiye'de 3 ay kadar kalacak ve Türkiye'deki incelemelerini iki rapor olarak bakanlığa sunacaktır (Bal, 1991: 49).

\section{John Dewey'in 1924 Tarihli Raporu}

J. Dewey'in Türkiye'de yazdığı rapor ile Amerika'dan gönderdiği iki rapor birbirini tamamlar niteliktedir. Bunlardan biri rapordan ziyade acil olarak bütçeye konulması gereken ödeneklerle ilgili tekliflerdir. Diğer rapor ise J. Dewey'in Amerika'ya döndükten sonra yazdığ ' "Esas Rapor" dur. J. Dewey, esas raporun giriş kısmında; "ilk ve pek mühim nokta, Türkiye mekteplerinin gaye ve hedeflerini tespit etmektir" diyerek, açık olarak hedefi belirlenmiş bir programla ancak eğitim kurumlarının lüzumsuz değişikliklerden ve sözde 1slahat adına yapılacak olan etkisiz tedbirlerden de korunacağını yazmıştır. Türkiye'de Maarif Teşkilatı'nda takip edilecek gayeyi tayinde sorun olmadığı ve Türkiye'nin medeni milletler arasında mükemmel bir uzuv olarak canlı, hür, müstakil, laik bir Cumhuriyet olarak geliştiğini belirtir (Dewey, 1990: 5).

Dewey, bu giriş çerçevesinde raporunda aşağıda belirtilen başlıklarda sorunları ele alır:

1-Program

2-Eğitim Bakanlığ 1 Teşkilatı

3- Öğretmenlerin yetiştirilmesi ve refahı

4-Öğretmenlerin yetiştirilmesi

5- Okul sistemi

6- Sağlik ve sağlığın korunması

7- Okul disiplini

\section{8- Çeşitli maddeler}

Dewey'in raporundaki bazı önerilerinde bazı tavsiyeleri dikkat çekmektedir. Özellikle öğretmen okullarının belli alanlarda öğrenci yetiştirmeyi sağlayacak ders çeşitliliğine sahip olması, en azından bir öğretmen okulunda bir "Deneyim Okulu”nun açılması ve öğretmenlerin kendilerini geliştirebilmeleri için okul kulüplerinin kurulması, eğitimle ilgili kitapların okunması, bu kitapların tartışılması, çeviriler yapılarak yabancı ülkelerdeki gelişmelerden haberdar olarak, kendi deneyimlerini paylaşacakları bir ortamla eğitimi tekdüzelikten kurtararak, okulları çeşitli bilimsel çalışmalara imkân sağlayan kurumlara dönüştürmenin mümkün olduğunu belirtir.

J. Dewey aynı zamanda okul sistemiyle ilgili olarak temel sorunlardan bazılarına da değinir; okul sisteminin her parçasının kendi içinde bir bütünlük arz etmesini, okulların ilkokuldan itibaren programlarını üniversiteye hazırlamak amacıyla düzenlediklerini ve bunun neticesinde "ilk ve ortaokulu bitiren ve üniversiteye gitmeyen öğrencilerin kendilerini ifade edebilecek ve bir mesleğe yönelecek imkanlardan yoksun olduğunu ve bunun için bir öğrenci ister üniversiteye gitsin, ister gitmesin kendine belli bir amaç edinmiş olmalıdır” der.

J. Dewey ders programlarının düzenlenmesi ile ilgili tavsiyelerde bulunur;

Müfredat programlarının memleketin çeşitli yerlerinde mahalli ihtiyaca uyum sağlayacak şekilde düzenlenmelidir. Okul dersleri ile hayat arasında bir bağ oluşmalıdır. Bu şekilde ülkenin o günkü şartlarının ele alınmasını ister. İlkokuldan sonraki okulların tarım, endüstri ve ticari olarak çeşitli alanlara ayrılmasını, bunun dışında belli şehirlerde fen ve yabancı dilde eğitim veren okulları açılmasını tavsiye eder. Yabancı dil olarak Fransızcadan başka birkaç yabancı dilin de okulun amaçları ve bölgesel ihtiyaçlara göre belirlenmelidir. 
Üniversiteleri incelemek için yeterince vakti olmayan Dewey, üniversitelerin düşünce gelişimine katkı sağlayacak nitelikte oluşmasını, başarılı öğrencilerin yurt dışına gönderilmesini ve İstanbul Üniversitesi bünyesinde bir arkeoloji bölümü kurulmasını da tavsiye eder.

J. Dewey, halk sağlığı ile ilgili olarak da okullarda uygulamalı sağlı bilgisi konmasını ve özel olarak yetiştirilen kadınların ev hanımlarına kendi evlerinde sağlıkla ilgili konularda bilgiler vermesini belirtmiştir.

Dewey raporun son bölümünde özel okullar ve resmi okullarla ilgili bir karşılaştırma yaparak, resmi okulların daha geleneksel olmalarına karşın, özel okulların yeni yöntemleri kullanma konusunda tecrübelerini geliştirme imkanına sahip olduğundan ve bundan dolayı yeniliklere ve yeni uygulamalara daha açık olduğunu belirttikten sonra, Türk eğitiminin menfaati gereği, gerek yabancı özel okullarla gerekse yerli özel okullarla daha çok işbirliği içerisinde olunarak, milli eğitim için yararlı uygulamaların tecrübe edileceği, bu şekilde Türk eğitimcilerinin yabancı memleketlere kadar seyahat etmeden, para ve zaman harcamadan çeşitli eğitim yöntemleri, okul yönetimi ve öğretim hakkında araştırma yapma imkanına sahip olacaklarını belirtir.

J. Dewey raporun sonunda Mr. Crain'e ve ilgili olan ve yardım eden herkese teşekkür ettikten sonra Türk eğitimine faydalı olması umudunu belirterek tamamlar (Dewey, 1990: 5-36).

\section{Atatürk Dönemi Eğitim Politikası}

Atatürk, Cumhuriyet'in kuruluşundan itibaren siyasi, sosyal, kültürel ve ekonomik birçok alanda yenilikler yaparak, modern ve çağdaş bir devlet düzeni oluşturmaya çalışmıştır. Denilebilir ki, yeni Cumhuriyetin mimarları, bu süreç içerisinde "halkın eğitimine büyük önem vermişler ve üzerinde en çok durdukları mesele eğitim meselesi olmuştur. Modern bir devlet olabilmek için inkılapların kabul görmesi, benimsenmesi, uygulanması ve geliştirilmesi, için en öncelikli konu eğitim olmuştur (Lowe, 1985: 23).

Eğitimli, kültürlü bir toplum öncelikle kendisinin gelişmesi ve yükselmesi için doğru şeyler yapma gayretinde olacaktır. Belli amaçlar doğrultusunda hareket eden toplumlar içinde yaşadığ 1 devlet bundan doğrudan etkilenecektir (Geray, 2002: 3).

Atatürk, Osmanlı Devleti yönetiminin aksine halk ile hareket etmiştir. Atatürk, yeni kurulan devletin "halk devleti" olduğunu ifade etmiş, milli egemenlik ilkelerini çalışma programının esası sayan kuvvetli bir halk yönetiminin temelini atmıştır (Atatürk, 2006: 562).

Yeni kurulan devletin bir halk devleti olduğu vurgulandıktan sora, eğitim seviyesi düşük bir halkın yönetime yön vermesi düşünülemezdi. I. TBMM' den itibaren eğitim konusu üzerinde büyük bir hassasiyetle durulmasına karşın, Cumhuriyetin ilanından sonra daha gerçekçi ve akılcı bir şekilde eğitim konusu ele alınmış ve öncelik verilmiştir (Akgün ve Uluğtekin, 1989: 285).

II. Meşrutiyet döneminde de eğitimde çağdaşlaşma adına çok şey yapılmış, yeni programlar ve raporlar hazırlanmış (Karagöz, 2019: 9,23,43) fakat savaşlar eğitimi büyük kesintiye uğratacaktır. İnsan gücüne duyulan ihtiyaç ve ailelerin çocuklarını okula göndermemesi, halkın eğitim seviyesini iyice azaltmıştır. Zor koşullar içerisinde kazanılan milli mücadele yıllarından itibaren Atatürk, çağdaşlaşma yönünde adımlar atılması ve bu adımların toplum tarafından benimsenmesi için ihtiyaca cevap vermeyen kültür ögelerinin terk edilmesini istedi (Tongül, 2004:110).

Modern bir toplum oluşturmanın sadece kanunlarla mümkün olmadığını bilen Atatürk, çocuk ve gençlerin, özellikle köylerde yaşayanların, eğitim imkanlarından yoksun olması ve halkın büyük bir kısmının okuma yazma bilmemesi, Atatürk'ün önceliğini eğitim reformu oluşturmuştur (Çeçen, 2000: 81).

Atatürk Cumhuriyet' in kurulması ile eğitim konusuna ağırlık vererek bir program dahilinde hareket etmiştir (Geray, 2002: 40-42). 
Atatürk, mevcut eğitim durumu ile ilgili şu tespitlerde bulunmuştur:

1. Toplumumuzda yaygın bir bilgisizlik vardır.

2. Eğitim öğretim yöntemlerimiz uygun değildir.

3. Çocuklarımız üzerinde ailenin baskısı vardır.

4. Bir toplumun yükselmesi ve alçalması da milli olup olmamasıyla ilgilidir, bizim eğitimimiz milli değildir.

5. İstikrarlı eğitim politikamız yoktur.

6. Eğitimimizin amacı, kendini, hayatı bilmeyen, her konuda yüzeysel bilgi sahibi, tüketici insan yetiştirmek olmuştur.

Atatürk eğitimle ilgili sadece tespitlerde bulunmakla kalmamış, aynı zamanda devlet için yeni bir eğitim felsefesi ve politikası da belirlemiştir (Akyüz, 2007: 336-338).

Atatürk kendisi Maarif vekili olmamasına rağmen, kendi dönemine damgasına vuracak olan ve kendi tespit ettiği ilkelere uygun kanunlar hazırlattı. Bu kanunları hayata geçirmek için oluşturulan komisyonlara başkanlık etti ve bu çalışmaları yakından takip etti (Özkan, 2014: 107).

Atatürk döneminde yeni eğitim sisteminin nasıl yönlendirileceği ve kanunların görüşülmesi amacı ile Heyet-i İlmiye toplantıları yapmıştır. Birinci Heyet-i İlmiye 15 Temmuz - 15 Ağustos 1923 de toplanmıştır. Birinci Heyet-i İlmiye 'de ilkokul programlarındaki değişiklikler yer almamıştır. 1924 yılında yapılan "ikinci Heyet-i İlmiye" toplantısında ilköğretim, ortaöğretim ve öğretmen okullarının süreleri ile ders kitaplarının yazdırılması gibi konularda kararlar alınmıştır (Öz, 2014: 131).

1924 programı, daha çok geçiş program özelliği göstermektedir. Bazı derslerin eklenmesi ve çıkarılmasıyla Cumhuriyet yönetimine uyarlanmaya çalışılmasıdır.

J. Dewey'in 1924 'te hazırlamış ve Türk Maarifi 'ne sunmuş olduğu rapordaki bazı önerilerin, 1926 programına yansıdığı görülmektedir. 1926 programıyla, dersler arasındaki ilişkilere önem verilmiş, eski programda "Tabiat Tetkiki", "Yurt Bilgisi", "Tarih ve Coğrafya", "Sağlık Bilgisi" dersleri ayrı ayrı gösterilirken yeni programda bu dersler "Hayat Bilgisi" adı altında birleştirilmiş ve eğitimin bel kemiğini oluşturan mihver ders olarak kabul edilmiştir (Hayat Bilgisi, 2013:20).

1926 programı, diğer programların yanında ayrı bir öneme sahiptir. Bugünkü programların dayandığı temel esasları içermektedir. 1926 programı, bugünkü programların dayandığı altı temel esası kapsaması bakımından da önemlidir.

1. Toplu öğretim sistemi

2. İlkokul amaçları

3. Derslerin özel amaçları

4. Öğretimde takip edilecek yollar

5. I İlk okuma-yazma öğretiminde uygulanan çözümleme yöntemi

6. 5 sinıflı ilkokulun birinci ve ikinci devreye ayrılması (Zan vd., 2016: 192-202).

\section{John Dewey Raporunun Mustafa Necati Dönemine Etkileri}

Mustafa Necati, Atatürk' ün inkılapları gerçekleştirme kadrosunda, en ön sıralarda yer alan bir Milli Eğitim Bakanıdır. Mustafa Necati'nin bakanlığından bir yıl önce Türkiye 'ye gelen J. Dewey' in raporu eksiksiz uygulanmaya çalış1lmıştır diyebiliriz (İnan, 1980: 17). 
Dewey, hazırlamış olduğu raporda, demokrasi ve eğitim anlayışı çerçevesinde bakanlığın rehber ve esin kaynağı olmakla birlikte, yönetimi ele almasını da ifade ediyordu. Dewey' in "öğretmen nasıl olursa, okullarda öyle olur" sözlerini, okulları iyileştirme ve yaşam kalitesinin yükseltilmesini, öğretmenlerin yaşam şartlarının düzeltilmesine ve niteliklerinin geliştirilmesine bağlı görüyordu. M. Necati, Dewey'in belirttiği eğitimdeki sorunları görerek çözüm yolları arar. M. Necati, eğitim sorununun çözümünün öğretmen yetiştirme ile yakından ilişkili olduğunu da fark eder.

M. Necati döneminde Dewey'in önerilerine uygun olarak, ortaokullara öğretmen, ilköğretime müfettiş yetiştirmek, araştırma ve incelemeler yaparak yayınlamak, dünyanın her yanındaki eğitim akımlarını izleyerek okullara yaymak amacı ile Gazi Öğretmen Okulu ve Gazi Eğitim Enstitüsü kuruldu.

M. Necati ile Dewey'in okul ve eğitim anlayışları arasında ciddi benzerlik vardır. Dewey, okulun amacını iki yönlü olarak görmektedir; Birincisi, milli yarar sağlayan bilgilerin toplanması ve basımını yapan bir merkez durumuna gelmek, ikincisi; öğrenciyi ülkeye yararlı olacak düşünce alışkanlıkları kazandırmak. Kısacası Dewey, Türkiye'de üretken, temel yaşam becerilerini esas alan, yetenekleri geliştirici ve demokratik esaslara bağlı çağdaş okulların yaygınlaştırılmasını önermişti.

Mustafa Necati, eski ve yeni eğitimin karşılaştırmalarını yaparak, Dewey'in tespitlerine benzer tespitler yapar. Eski okullar ezberciliğe dayandığından kişisel yeteneklerin gelişimine engeldir. Aynı zamanda eski okulların ulusal ve demokratik bir yapısı yoktur (Bal, 2010: 69-76).

Mustafa Necati, Türkçeye çevirterek kendi imzasıyla öğretmenlere ve öğretmen okullarına armağan ettiği "Beyaz Zambaklar Memleketinde" Dewey' in "Demokrasi ve Eğitim" kitaplarıyla gözleri eğitime, halkın eğitimine, köye, topluma ve eğitimin gücüne çevirmek istiyordu (İnan, 1980: 37-38).

Sonuç olarak Mustafa Necati, hem J. Dewey'in "Demokrasi ve Eğitim" anlayışından etkilenmiş, hem de J. Dewey'in raporunda yer alan önerilerinin tamamına sahip çıkmış ve Cumhuriyet'in koşulları içerisinde gerçekleştirmeye çalışmış bir milli eğitim bakanıdır.1929' da M. Necati'nin ölümünden sonra da eğitimle ilgili çalışmalar Atatürk'ün ölümüne kadar kesintisiz devam etmiştir. Bu çalışmaların içerisinde Halkevlerinin açılması eğitim, kültür ve demokrasi adına çok önemlidir.

\section{Atatürk ve Halkevleri}

Halkevleri, tarihsel gelişim ve oluşum sürecinde doğmuş ve yeni Türkiye Cumhuriyeti’nin geniş anlamıyla Türk inkılabının, toplumsal bir değişim ihtiyacı olarak ortaya çıkmıştır. Atatürk, ulus olmanın ve ulusça kalkınmanın tek sihirli anahtarının halkın gücünde olduğuna inanmış ve bu düşünceyle önce halkın eğitilmesi, yetiştirilmesi ve çağa uyabilmesi için de bazı deneylerden sonra halkevlerini kurdurmuştur (Kaplan, 1974: 51-52).

Halkevlerinin açılma haberini veren Akşam Gazetesi de kültür devriminin gerçekleşmesi ve ülkenin gelişmesi için halkevlerinin çok önemli bir rol üstlendiğini yazmıştır (Akşam, 20 Şubat 1932).

Halkevleri, kültür inkılabının alt yapısında önemli roller üstlenmişti. Özellikle köylerin de kalkınmasının yolunu açarak devlet-millet bütünleşmesini de sağlayacaktı (BCA, 10 Kasım 1936).

Türkiye'nin birçok ilinde İstanbul'dan Hakkari'ye belli dönem aralıklarıyla ve koşulların hazırlanması ile açılan halkevleri için Cumhuriyet Gazetesi, "Halk Dün Kendi Evlerini Açtı" başlı̆̆ıyla halkevlerinin bir halk merkezi olduğu haberini vermiş̧tir (Cumhuriyet, 20 Şubat 1932).

\section{Sonuç}

Sonuç olarak, J. Dewey, eğitimin demokrasiyi gerçekleştirmedeki önemli gücünü vurgularken aynı zamanda bu gücü kullanmanın önemini de ortaya koyar. Bunun için de halkın 
topyekûn eğitilmesi gerekir. Dewey'e göre Cumhuriyeti ve demokrasiyi yaşatacak nitelikte yurttaş yetiştirmek için öncelikle halkın ihtiyaçlarından yola çıkarak halkın eşitlik ilkesi ile eğitilmesi ve bilinçlendirilmesi gerekir.

Atatürk'ün ölümüne dek yapılan çalışmalara bakıldığında; halkı yönetime katmak, halkın bilgi ve bilinç seviyesini artırmak ve bu yönde kurumlar açarak kültürel kalkınmayı sağlamak ve eğitimi bir araç olarak görmek suretiyle bu amaçların gerçekleştirilmiş olduğunu söyleyebiliriz. Özellikle Atatürk döneminde Milli Eğitim Bakanı Mustafa Necati Dönemi’nde J. Dewey raporunun çok önemli bir esin kaynağı olduğu ve öğretmenlere verilen değerle birlikte; öğretmenlerin kendini geliștirebileceği koșulları hazırlama, öğretmenlere dağıtılan” Demokrasi ve Eğitim” kitabı ile öğretmenlerin okumaya teşvik edildiği görülmektedir. J. Dewey'in öncelikli olarak gördüğü öğretmen yetiştirme konusunun da öncelikle ele alınması ve öğretmen okullarının açılması da bunu en önemli göstergesidir.

1926'da hazırlanan programın 1924 programın göre daha kapsamlı ve bugünkü programların temelini teşkil edecek nitelikte olması, J. Dewey raporundaki derslerle ilgili önerilerinin dikkate alındığını göstermektedir.

Atatürk Dönemi'nde Türk Ocakları'nın kapatılmasından sonraki süreçte halkevlerinin açılmasıyla ve bütün halkın köylüsüyle, kentlisiyle halkevi faaliyetlerinin içinde olması, demokrasinin eşitlik, adalet, halk katılımı ve vatandaş olma ilkelerinin en iyi uygulandığı bir alan olduğunu ortaya koymaktadır. Bu nedenle J. Dewey'in "Demokrasi ve Eğitim" adına milli egemenlik esasına göre kurulan devletlerde yapılması gereken felsefe, çalışma ve uygulama örneklerinin hemen hemen büyük çoğunluğunu halkevlerinin açılış amaçlarında ve faaliyetlerinde görmek mümkündür.

\section{Kaynakça}

Akgün, S ve Uluğtekin, M. (1989). Misak-1 Maarif. Ankara Üniversitesi Türk Inkllap Tarihi Enstitüsü, Atatürk Yolu. (3), 285-349.

Akyüz, Y. (2007). Türk Ĕ̌itim Tarihi. Ankara: Pegem.

Ata, B. (2001). 1924 Türk Basını Işığında Amerikalı Eğitimci John Dewey’in Türkiye Seyahati. G. U. Gazi Ĕ̈itim Fakültesi Dergisi. 21(3), 193-207.

Ata, B. (2013). Amerikalı İş Adamı Hayırsever ve Diplomat Charles R. Crain'in Türkiye'deki Kültür ve Eğitim Faaliyetleri. Kuruluşundan 90. Yılına Türkiye Cumhuriyeti Uluslararası Sempozyumu. Eskişehir: Atatürk Araştırma Merkezi Yayınları.

Atatürk, M.K. (2006). Atatürk'ün Söylev Demeçleri. Ankara: Atatürk Araştırma Yayınları,

Bal, H. (1991). 1924 Raporunun Türk eğitimine Etkileri ve J. Dewey'in Eğitim Felsefesi. İstanbul: Aydınlar Matbaası.

Bal, N. (2010). John Dewey'in Eğitim Felsefesi. İstanbul: Fakülte Kitabevi.

$B C A, 3.14 .6$ (10 Kasim 1936)

$B C A, 80.10 .0$. (06.08.1923)

$B C A, 84.57 .0$. (26.09.1923)

$B C A, 96.38 .0 .(03.02 .1924)$

Çeçen, A. (2000). Atatürk’ ün Kültür Kurumu Halkevleri. İstanbul: Cumhuriyet Kitapları.

Dewey, J. (1964). Özgürlük ve Kültür. İstanbul: Çan yayınları. 
Dewey, J. (1990). Türkiye Maarifi Hakkında Rapor (1924). Ankara: Çıraklık ve Yaygın Eğitim Genel Müdürlüğü, Mesleki ve Teknik Açık Öğretim Okulu Matbaası.

Dewey, J. (2004). Demokrasi ve Eğitim. Ankara: Yeryüzü Yayınevi.

Dewey, J. (2014) Deneyim ve Eğitim. Ankara: ODTÜ Yayıncılık.

Doğa, İ. (2004). Toplum ve Eğitim sorunları üzerine Felsefi ve Sosyolojik Tahliller. Ankara: Pegem.

Gazi'nin Yeni Eseri. Cumhuriyet. 20 Şubat 1932.

Geray, C. (2002). Halk Eğitimi. İstanbul: İmaj Yayınc1lık.

Halkevleri Her Tarafta Büyük Merasimle Açıldı. Akşam. 20 Şubat 1932.

Hayat Bilgisi öğretmen El Kitabı. (2013). Ankara: Pegem.

İnan, M. R. (1980). Mustafa Necati, Kişiliği, Ulusal Eğitime Bakışı, Konuşma ve Anıları. Ankara: Türkiye İş Bankası Kültür Yayınları.

Kaplan, K. (1974). Atatürk ve Halkevleri, Halkevlerinin Doğuş Bilinci ve Tarihsel Görevi. Ankara: Türk Tarih Kurumu Basımevi.

Karagöz, S. (2019). Cumhuriyet Dönemi Eğitimine Yön Veren Yerli ve Yabancı Raporları (19111927). Ankara: Pegem.

Lowe, J. (1985). Dünyada Yetişkin Eğitimine Toplu Bakış. Ankara: Unesco Türkiye Millî Komisyonu.

Öz, A. (2014). Heyet-i İlmiye Toplantıları ve Millî Eğitim Şuralarında Din Eğitimi. Sakarya Üniversitesi Illahiyat Fakültesi Dergisi. 16(29), 129-156.

Özkan, S. (2014). Türk Eğitim Tarihi. Ankara: Nobel Yayıncılık.

Özsoy, S. (2009). Türk Modernleşmesi, Demokrasi ve Eğitim: Dewey Perspektifizminden Bir Çözümleme. Kuram ve Uygulamada Eğitim Bilimleri / Educational Sciences: Theory \& Practice. 9(4), 1895-1931.

Tongül, N. (2004). Türk Harf İnkılabı. Ankara Üniversitesi Türk İnkllap Tarihi Enstitüsü, Atatürk Yolu. (33), 103-130.

Yeşiltaş, N. K. ve Kaymakçı, S. (2009). John Dewey'in Eğitim Anlayışı ve Sosyal Bilgiler Eğitimine yönelik, Bazı örnek Uygulamaları. Sosyal Bilimler Enstitüsü Dergisi, Journal of the lstitute of Social Sciences. (4), 227-242.

Y1lmaz, Z. (2009). John Dewey'in Liberalizmi, Bireycilik, Toplum ve Özgürlük, Felsefe Dergileri Bibliyografisi (I). Kaygı. (12), 79-92.

Zan, N, Efe, A. Ve Zan, B. U. (2016). 1927 ilk Mekteplerin Müfredat Eşya Dersi Programı. Ĕğitim ve Ögretim Araştırmaları Dergisi. 5(1), 191-203. 